\title{
Challenges Faced by School Education in the New Media Era
}

\author{
Cai Baojing ${ }^{1 *}$ Zhu Yongfei ${ }^{2}$ Chen Tingmei ${ }^{3}$
}

\author{
${ }^{1}$ Department of Public Administration, Nan fang College of Sun Yat-sen University, Guangzhou, Guangdong, 510000, \\ China \\ ${ }^{2}$ Department of Public Administration, Nan fang College of Sun Yat-sen University, Guangzhou, Guangdong, 510000, \\ China \\ ${ }^{3}$ Department of Public Administration, Nan fang College of Sun Yat-sen University, Guangzhou, Guangdong, 510000, \\ China \\ *Corresponding author. Email: 35247838@qq.com
}

\begin{abstract} suggestions.

\section{Preface}

With the rapid development of science and technology in the 21 st century, we have entered the era of new media. Science and technology has brought great changes to all aspects of our lives. In recent years, new media have broken into the field of school teaching and promoted the reform of education mode. New media are just like a double-edged sword, which brings a lot of convenience to teaching, such as making the classroom flexible and diverse, promoting students' interest in learning and so on. At the same time, it also brings some challenges to school education, which are often difficult for educators to grasp. This paper will explain the challenges of school education from the following aspects.
\end{abstract}

In recent years, new media has developed rapidly, occupying almost every class in primary and secondary schools. It brings us many conveniences and challenges to school education. This paper expounds the challenges faced by school education in the new media era from three aspects: the difficulty of teachers' class, the difficulty of knowledge internalization and the difficulty of moral education, and puts forward relevant

Keywords: New Media, school education, online teaching, micro class

\section{The difficulty of teachers in class increases}

Nowadays, multimedia is widely used in everyone's life. Unlike in the past, students' learning only depends on the teacher's explanation in class. They can learn the knowledge they want by watching micro class video on the Internet or listening to live class. If teachers only teach book knowledge and do not expand it, it is difficult to meet the diverse needs of students. For example, students in junior high school need to take an English test now, but everyone needs different types of tests. For example, some just want to finish the final English test、 some need to take CET-4 or CET-6 and other need to pass the English test at the time of postgraduate entrance examination. If the teachers in the school only teach the knowledge in the College English textbook in class, it is not enough to help the students pass the CET- 6 and the postgraduate entrance examination. Not everyone only listens to the English classes offered by the teachers in the school. Some students can meet their own needs through online classes, such as New Oriental's English online classes. In the case that listening to online classes can meet their own learning needs, students will not listen to classes. At this time, teachers need to have a unique insight, carefully observe each student, do a lot of investigation, find out what knowledge the students want to learn before class, or the recent development zone of the students, mobilize the students' desire for knowledge, try to make the content they teach is the most needed knowledge of the students, and urge the students to listen carefully. But if many years ago, when the new media was underdeveloped, the only source of knowledge for most students was to listen to what the teacher taught in class. Every student who wanted to know would listen to what the teacher said in class. The learning atmosphere in the class would be very strong, and the difficulty of the teacher's class would be relatively reduced.

\section{The difficulty of knowledge internalization increases}

Now in the process of classroom teaching in primary and secondary schools, almost every class has PPT courseware or an audio or video. Although this teaching mode enriches the classroom, arouses students' interest and improves their attention in class. However, new media is also easy to bring primary and middle school students to learn the cart before the horse, knowledge internalization difficulty increased. Because people's energy is limited, especially for primary and middle school students, it is 
difficult for them to concentrate in a class for 40 minutes, students in a class will be relatively focused and relatively distracted. In general, in a class, the teachers in the classroom a large screen display video or pictures, the students' attention is the most concentrated, because the video and photo is different from the teacher's teaching, it is fresh and colorful for students, new things always can attract students curiosity, video and images can be very effective to hold the vision of students and attention. Video or photos, of course, there is knowledge, but in many cases, a class of core knowledge is not fully presented in the form of video or photos, watching the video or pictures, the students' attention is very concentrated, but after watching the video, their energy will be less, if the teacher and then to the interpretation of core knowledge, students may be thought to keep up with, or knowledge internalization of difficulty will increase. For example in the drama "thunderstorm" the interpretation of the text, many teachers are sometimes put drama "thunderstorm" more than ten minutes of video, in this way to help students understand the relationship between the characters, arouses student's study enthusiasm, but when watching the video, the students' attention is likely to be on the character's actions, affectionate, and language, after watching the video, students focus point is not all on the relationship between characters, some students may discuss the actor very not good-looking, how where is the dress special and actors acting and so on Therefore, showing students videos in class does not guarantee that each student's focus is on the relationship between the characters in the play. Even if students concerned about the character of complex relations, in the teacher explained the difficulty of the lesson, reveals the semi-feudal and semi-colonial society $\mathrm{Fu}$ Xiu Xing, students it is difficult to listen with rapt attention, this is the place where a student is not easy to understand, if students not highly focused at this time, it will be difficult to analyze the deep connotation of the text, the difficulty of knowledge internalization

\section{The difficulty of moral education increases}

Multimedia is a double-edged sword, we can not only get more knowledge we want to know and enjoy our body and mind through multimedia, but it is also very easy to suffer the influence of bad information on the Internet. The three views of adults have been formed, and they have relatively perfect ability to judge and analyze information, and are easy to resist the intervention of bad information. However, most of the primary and middle school students receiving education in schools are minors, who are not perfect in their cognition of the world, and do not have enough judgment ability to distinguish right from wrong. Now they are in this period of time to form their own three view of the age, it is easy to be affected by multimedia bad information, not easy to resist the temptation of sex, gambling and drugs. In modern society, information is so complicated and complicated that students can search the Internet directly by opening their mobile phones and computers. Some of the information on the Internet can lead to early puberty, or online gambling, violence and so on. According to Locke's "whiteboard theory", the human mind is born like a blank sheet of paper, and it is experience that provides spiritual content. Even if there are values and ideological and political education in the school curriculum, it is not the only source for students to receive information. In such a complex environment in modern society, students tend to develop some bad habits and form incorrect three views. "Learning notes" in the mention of "hair and then ban, is defending and defeated. It means that once something happens, it's forbidden, the habit is so ingrained that it's hard to get rid of it. If a student has developed bad habits, it will have a deviation in his life and the cognition of society. It is not easy for him to correct it only through school education. Therefore, the development of new media increases great difficulty for the implementation of moral education in school.

\section{Coping strategies of Contemporary Teachers}

In the face of the great challenges brought by new media, teachers need to be calm and calm, carefully analyze the causes of the challenges, and come up with solutions. In the face of great challenges, teachers should first look for solutions from their own body, expand their scope of knowledge, enrich their knowledge, and research knowledge to have a certain depth, to know how, and why. When giving a lecture, we should not only give students the knowledge in the textbook thoroughly, but also explore the deep meaning and value of the text. Teachers should also has advanced education ideas and education concept, high school teaching material reform in recent years, for example, increase the learning task group of units, advocate group article reading and read the whole book, and so on, the teacher should know the concept, and apply these ideas to practice, to build a teachers as the leading factor, the student as the main body of lively classroom. Secondly, teachers should reasonably set up every link of the whole class and reasonably arrange time. A class only lasts 40 minutes. Teachers should not only explain the knowledge points in class to students, but also lead students to break through the key points. The teacher should integrate the new media into the classroom and make it the highlight of the classroom teaching, instead of the tool for the teacher to simplify the teaching steps. For example, when talking about Lin daiyu entering jia fu, in order to save the teacher from spending a lot of time in class on the blackboard drawing a diagram of the relationship between the characters, the teacher can present the diagram of the relationship between the characters on the PPT when preparing the class, which not only saves a lot of time, but also makes the relationship between the characters clear at a glance. When playing the video, we should pay attention to control the length of time. We should not play the video endlessly, which 
hinders the normal teaching in class. What is most undesirable is that teachers use recitation audio to replace their own reading, which weakens the aesthetic experience of the class. Finally, teachers should permeate the education of emotion, attitude and values in daily teaching. Moral education is not only the task of moral education or political education, but also the task of moral education in subjects such as Chinese, history and geography. Do not make the Chinese class a language tool class, a good Chinese class should be both instrumental and humanistic. No matter what the course is, it should enable students to think about problems from multiple perspectives, and at the same time, it should enable students to view problems in life historically.

\section{Conclusion}

Every coin has two sides. The rapid development of new media contributes greatly to the promotion of education reform, but it also undoubtedly brings great challenges to school education and places more and more burden on teachers. As teachers in the 21 st century, we should be rich in knowledge, advanced ideas, fresh thinking to meet the challenge, school education to support a blue sky.

\section{Acknowledgment}

This research was supported by colleagues and students in Department of Public
Administration, Nan fang College of Sun Yat-sen University. Thanks them for their hard working.

\section{References}

[1] Li,X., (2020), Challenges Facing School Education in the new media era, Media Forum.

[2] Li,BL., (2019),Cultivation of school mainstream ideological identity in the new media era, , interview and compilation.

[3] Wang,B., (2019),Demand Analysis of Higher Education Management System in Media Age, satellite TV and broadband multimedia.

[4] Liu,L., Yang,XZ., (2017) The great influence of new media technology on advertising, Zheng Guoqiang; Art Technology.

[5] Feng,Y., (2014),Wang Liqing and Liu Xuhong's investigation on the construction of ideological and Political Education Network for college students in the New Media Environment J. Educational Exploration.

[6] Liang,Z., ( 2014), an innovative research on communication between home and school under the new media environment. Fudan University Press. 